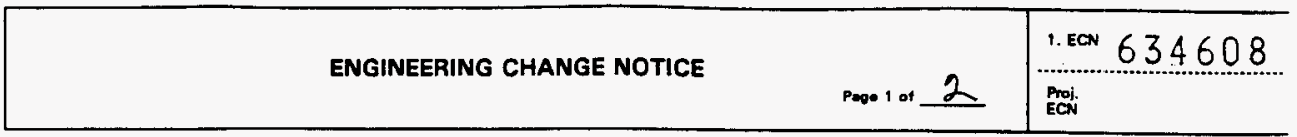

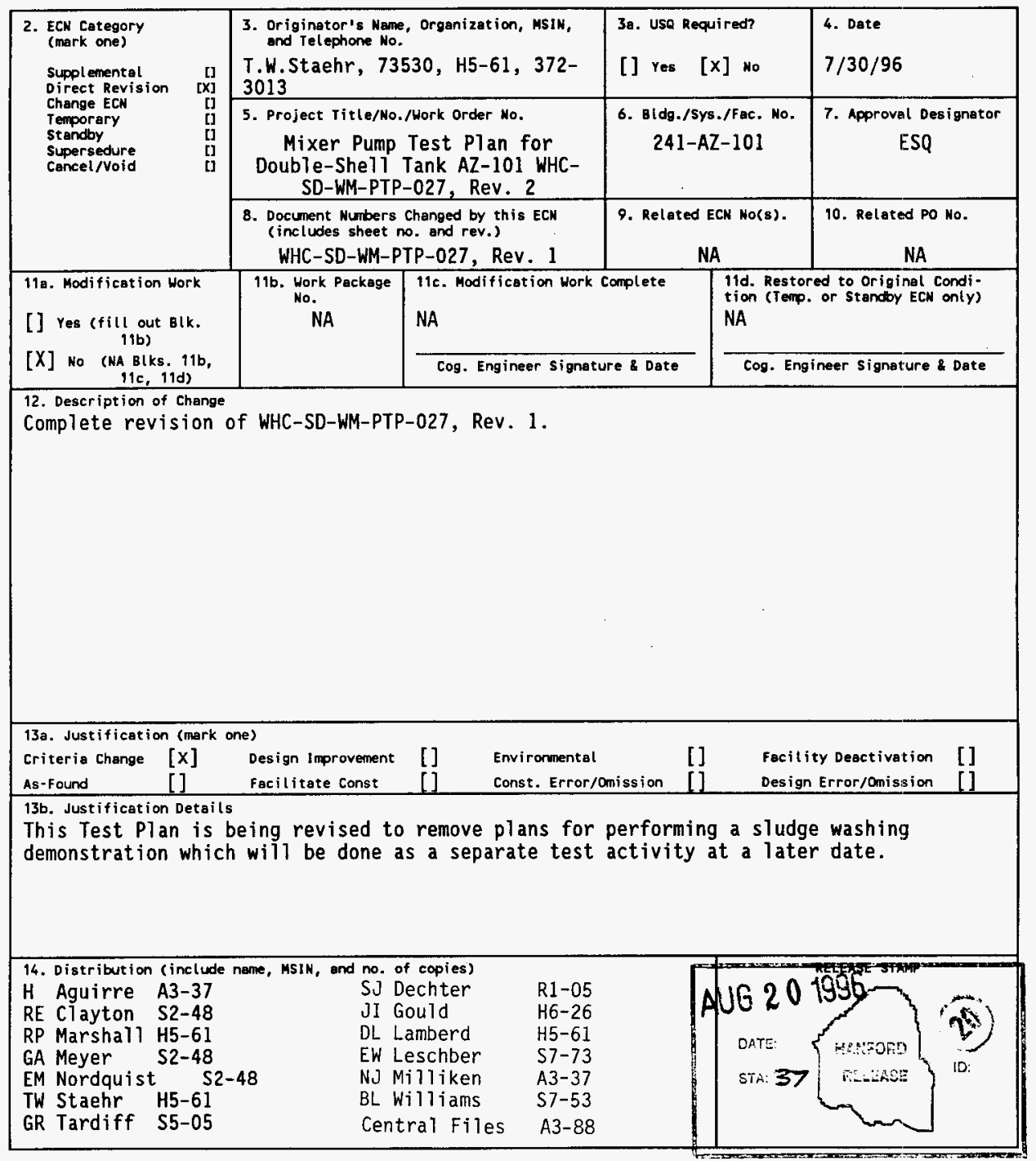

A-7900-013-2 (11/94) GEF095 


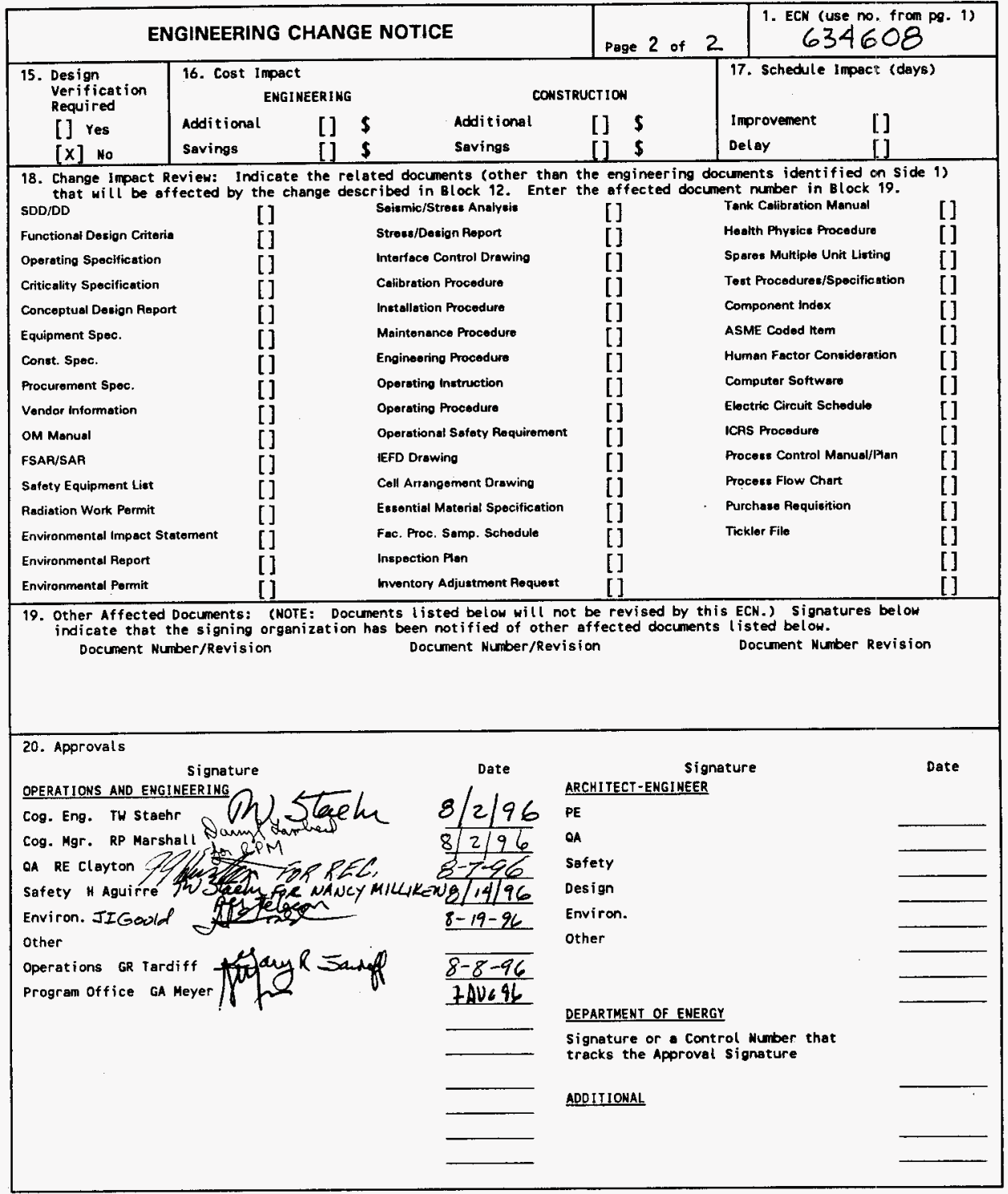




\section{Mixer Pump \\ Test Plan for Double Shell Tank AZ-101}

Gina A. Symons/Thomas W. Staehr

Westinghouse Hanford Company, Richland, WA 99352

U.S. Department of Energy Contract DE-AC06-87RL10930

\begin{tabular}{|c|c|c|}
\hline $\begin{array}{l}\text { EDT/ECN: } \\
\text { Org Code } \\
\text { B\&R Code: }\end{array}$ & $\begin{array}{l}634608 \\
73530 \\
\text { EW3130010 }\end{array}$ & $\begin{array}{l}\text { UC: } 721 \\
\text { Charge Code: } \\
\text { Total Pages: }\end{array}$ \\
\hline
\end{tabular}

Key Words: mixer pump, tank $A Z-101$, retrieval system

Abstract: Westinghouse Hanford Company has undertaken the task to develop and demonstrate a method of retrieval for double-shell tank (DST) waste. Mixer pumps were chosen as the planned method of retrieval for the DSTs, based on engineering technology studies, past experience with hydraulic sluicing at the Hanford Site, and experience with mixer pumps at the Westinghouse Savannah River Site. This document outlines a test plan to demonstrate the ability of two $300 \mathrm{hp}$ mixer pumps installed in the $A Z-101$ tank to mobilize waste.

TRADEMARK DISCLAIMER. Reference herein to eny specific commercial product, process, or service by trade name, trademark, manufacturer, or atherwise, does not necessarily constitute or imply its endorsement, recommendation, or favoring by the United States Goverment or any agency thereof or its contraciors or subcontractors.

Printed in the United States of America. To obtain copies of this document, contact: UHC/BCS Document Control Services, P.0. Box 1970, Mailstop H6-08, Richland HA 99352, Phone (509) 372-2420; Fax (509) 376-4989.

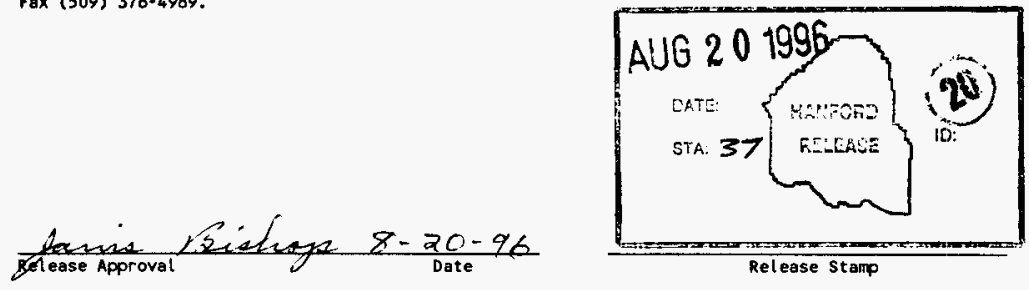


(2) Title

Mixer Pump Test Plan for Double-Shell Tank AZ-101

CHANGE CONTROL RECORD

\begin{tabular}{|l|l|} 
(3) Revision & (4) Description of Change - Replace, Add, and Delete Pages \\
\hline 0 & (7) EDT-605431 \\
\hline 1 & Complete revision. ECN 164966 \\
\hline 2 RS & Complete revision. ECN 634608 \\
\hline
\end{tabular}

Authorized for Release

(5) Cog. Engr. (6) Cog. Mgr. Dote 


\section{WHC-SD-WM-PTP-027, Revision 2}

\section{MIXER PUMP TEST PLAN FOR DOUBLE-SHELL TANK 241-AZ-101}

June 1996

G. A. Symons

T. W. Staehr

Westinghouse Hanford Company

Richland, Washington 


\section{TABLE OF CONTENTS}

1.0 INTRODUCTION ...................... . . . . . . . . . . .

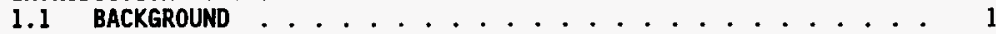

1.2 TEST OBJECTIVES . . . . . . . . . . . . . . . . 2

1.3 PREDICTED RESULTS ...................... . . . . 3

2.0 TEST EqUIPMENT AND INSTRUMENTATION . . . . . . . . . 4

2.1 MIXER PUMPS . . . . . . . . . . . . . 4

2.2 MIXER PUNP MONITORING AND CONTROL SYSTEM ........ 4

2.3 DATA ACQUISITION EQUIPMENT . . ............ 5

2.3.1 closed-Circuit Television . . . . . . . . . . 6

2.3.2 ENRAF Liquid Level .............. . 6

2.3.3 Gamma Profiler ................ . 6

2.3 .4 Thermocouples ................ 6

2.3 Strain Gauge .............. . . 7

2.3.6 U1 trasonic Interface Level Analyzer . . . . . . . 7

2.3.7 Ventilation System Monitoring Equipment . . . . . . 7

3.0 SAMPLING $\ldots \ldots \ldots \ldots$

4.0 TEST DATA ANALYSIS .................. 8

5.0 PROCEDURE . . . . . . . . . . . . . . . . . . 9

5.1 PRECAUTIONS AND LIMITATIONS . . . . . . . . . . . . . . . 9

5.1 .1 Pump operation ................ . . . 9

5.1.2 Motor Bearing Temperature . . . . . . . . . . . 9

5.1.3 Pump Motor Temperature . . . . . . . . . . . . . 9

5.1.4 Pump Current . . . . . . . . . . . . . . . 9

5.1.5 Minimum and Maximum Pump Operation ....... 10

5.1.6 Strain Limits for In-Tank Equipment .......... 10

5.2 GENERAL SEQUENCE FOR MOBILIZATION OF SOLIDS ........ 10

5.3 GENERAL SEQUENCE FOR MAINTAINING MOBILIZED SOLIDS IN $\ldots \ldots \ldots 11$

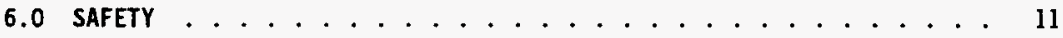

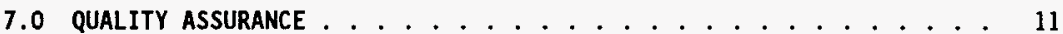

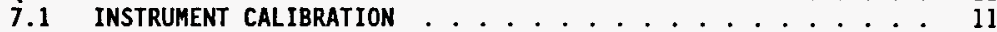

7.2 WITNESSING TESTS . . . . . . ......... 12

8.0 SCHEDULE $\ldots \ldots \ldots \ldots$

9.0 FUNCTIONAL RESPONSIBILITIES . . . . . . . . . . . . . . . . . 12

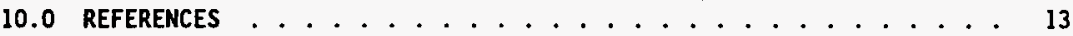




\section{TABLES}

Table 1. MIXER PUMP CHARACTERISTICS . . . . . . . . . . . . . . . . 4

Table 2. MIXER PUMP CONTROL CONSOLE INDICATION............ .44

Table 3. MIXER PUMP SYSTEM CONTROL LOGIC . . . . . . . . . . . . . 5

\section{FIGURES}

Figure 1. Location of Instrumentation to Monitor AZ-101 Process Test . . 14

Figure 2. Operational Thermocouples Which Will Monitor Sludge

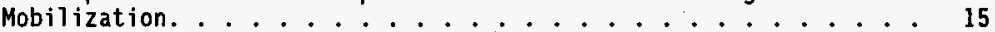

Figure 3. Operational Thermocouples Which Will Monitor STudge Mobilization with Indexing Areas . . . . . . . . . . . . 16

Figure 4. Mixer Pump Test AZ-101 Schedule . . . . . . . . . . . . 17 


\section{Acronyms and Abbreviations}

$\begin{array}{ll}\text { ASTM } & \text { American Society for Testing Materials } \\ \text { CAM } & \text { Continuous Air Monitoring } \\ \text { CCTV } & \text { Closed-Circuit Television } \\ \text { CSER } & \text { Criticality Safety Evaluation Report } \\ \text { D } & \text { Nozzle diameter } \\ \text { DST } & \text { Double-Shell Tank } \\ \text { ECR } & \text { Effective Cleaning Radius } \\ \text { K } & \text { Proportionality Constant } \\ \text { LCO } & \text { Limiting Conditions of Operation } \\ \text { NOC } & \text { Notice of Construction } \\ \text { OPC } & \text { Operator Personal Computer } \\ \text { OSD } & \text { Operating Specification Document } \\ \text { OSR } & \text { Operating Safety Requirements } \\ \text { PNNL } & \text { Pacific Northwest National Laboratory } \\ \text { T } & \text { Shear stress } \\ \text { TWRS } & \text { Tank Waste Remediation System } \\ \text { U } & \text { Fluid velocity } \\ \text { URSILLA } & \text { Ultrasonic interface level analyzer } \\ \text { USQ } & \text { Unreviewed Safety Question } \\ \text { VCR } & \text { Video Cassette Recorder } \\ \text { VFD } & \text { Variable Frequency Drive } \\ \text { WSRS } & \text { Westinghouse Savannah River Site } \\ \text { WVNS } & \text { West Valley Nuclear Services } \\ & \end{array}$


WHC-SD-WH-PTP-027, Revision 2

\section{MIXER PUAP TEST PLAN FOR DOUBLE-SHELL TANK 241-AZ-101}

\subsection{INTRODUCTION}

Westinghouse Hanford Company has undertaken the task to develop and demonstrate a retrieval method for double-shell tank (DST) waste. Mixer pump systems were chosen as the planned retrieval method for DSTs based on engineering technology studies, past experience with hydraulic sluicing at the Hanford Site, and experience with mixer pumps at the Westinghouse Savannah River Site (WSRS) and at West Valley (WVNS).

\subsection{BACKGROUND}

Although some mixer pump tests have been performed in actual waste tanks at the Hanford Site, those tests had different scope (mitigation of safety issues versus waste retrieval) using only one mixer pump. Retrieval work at WSRS and West Valley Nuclear Services has shown that more than one mixer pump must be used in a tank to achieve waste mobilization of a large fraction of the settled solids (Waters 1992). The Hanford Site DST waste is thought to be similar to the WSRS waste, and thus it is probable that multiple mixer pumps will be required.

Tank 241-AZ-101 has been selected as the first full-scale demonstration testing of a retrieval system. Tank $241-A Z-101$ is located in the AZ Tank Farm in the 200 East Area. The tank is a 3,785,400-1iter, (1 million-gal), 23meter $(75-\mathrm{ft})$ diameter double-shell underground storage tank. The tank currently holds over 900,000 gal of neutralized current acid waste, including approximately $45.7 \mathrm{~cm}$ (18 in.) of sludge (settled solids) at the tank bottom.

Project $W-151$ will provide two mixer pumps which will be installed and safely operated within the DST, along with certain ancillary equipment. Existing instrumentation in the tank, as well as additional instrumentation being installed, will be utilized during the test of the retrieval system following the Project $W-151$ completion. The test will be performed by Tank Farm Operations.

This test plan will provide the testing and evaluation of the mixer pump architectural solution for mobilization of DST sludges. The planned demonstration of mixer pump technology will provide comparisons with the predictive model, developed by the Pacific Northwest National Laboratory (PNNL), for estimating mixer pump performance (Powell 1995). 


\subsection{TEST OBJECTIVES}

The mixer pump system test goals are to effectively mobilize solids within the supernate, and to demonstrate actual in-tank operation of mixer pumps. Data gathered during the test will be used to provide further justification for using mixer pump retrieval systems in ten additional DSTs, per Project W-211, "Initial Tank Retrieval Systems". The purpose of the mixer pump test is to accomplish the following:

1. Confirm the mixer pump system operational goal of achieving $90 \%$ mobilization of the approximate $46 \mathrm{~cm}(18 \mathrm{in.})$ of solids which have settled to the $A Z-101$ tank bottom.

2. Determine the degree of solids mobilization for several pump speeds as a function of operating time (for individual pumps and both pumps).

3. Determine the minimum mixer pump speed required to maintain the mobilized solids in suspension.

4. Confirm the mobilization properties of tank 241-AZ-101 waste sludge by comparing test data with the empirical data obtained from the ECR equation, as projected from simulated wastes studied by the PNNL in laboratory tests. The anticipated $U_{0} D$ of $2.7 \mathrm{~m}^{2} / \mathrm{s}\left(29.4 \mathrm{ft}^{2} / \mathrm{s}\right)$ should be achieved at $1000 \mathrm{rpm}$. The ECR formula is
\[ E C R=K \cdot U_{0} \cdot D \cdot \tau_{\mathrm{s}}^{-0.67} \]

where,

$$
\begin{aligned}
& E C R=\text { effective cleaning radius, meters } \\
& K=\text { proportionality constant }=1,730 \\
& U_{0}=\text { fluid velocity, meters } / \text { second } \\
& D=\text { nozzle diameter, meters } \\
& \tau_{s}=\text { waste shear strength, dynes } / \mathrm{cm}^{2}
\end{aligned}
$$

5. Determine the actual ECR achieved and compare to calculated ECR based on PNNL developed equation (Powell 1995). Calculated ECR will be determined based on actual sample shear strength data obtained in 1989.

6. Provide a base to optimize the number and location of mixer pumps and the cleanout time cycles needed for various other Hanford tank wastie.

7. Determine mixer pump jet force on selected in-tank components and provide verification of models and laboratory data used to project forces on in-tank components.

8. Evaluate the operation and adequacy of mixer pump instrumentation and equipment and determine the instrumentation needs and operational improvements to be applied to future retrieval systems.

9. Determine the sludge settling rates and compare to predicted results from models.

10. Determine the effects of possible waste entrainment in the ventilation exhaust stream as a function of the mixer pump operating conditions. 
11. Evaluate the accuracy of the simplified DST heat removal program (Crea 1995) to predict DST waste temperature increase during mixer pump operation by comparing actual data to the predicted data.

\subsection{PREDICTED RESULTS}

The following are the expected results of the test:

1. The mixer pump system will mobilize $90 \%$ of the solids that have settled to the tank bottom.

2. The initial sludge settling rate after the mixer pumps are turned off will be determined. A sludge settling rate of about $2 \mathrm{~cm} / \mathrm{hr}(.79 \mathrm{in} / \mathrm{hr})$ is expected based on laboratory tests with simulants and actual waste.

3. The maximum combined force predicted from the two mixer pumps jets on selected in-tank components is $76 \mathrm{Kg}(167 \mathrm{lb})$.

4. No increase in radioactive emissions are expected due to mixer pump operations.

5. Instrumentation and equipment used to monitor the mixer pump system test will be evaluated for reliability, adequacy, and operability to determine instrumentation requirements for monitoring future retrieval systems.

6. After initial mobilization of the sludge at full speed operation, it is expected that the mixer pumps need be run at minimum speed (700 rpm) to maintain sludge mobilization.

7. An effective cleaning radius of $9.8 \mathrm{~m}(32.2 \mathrm{ft})$ is expected with the pumps operating at $1,000 \mathrm{rpm}$, if the assumed shear strength of 10,000 dynes $/ \mathrm{cm}^{2}$ and the PNNL developed ECR correlation are correct.

8. At full-speed operation of the two mixer pumps, the predicted waste temperature increase will be less than $0.0833^{\circ} \mathrm{C} / \mathrm{hr}\left(0.15^{\circ} \mathrm{F} / \mathrm{hr}\right)(\mathrm{Crea}$ 1995).

9. A reasonable duration of mixing waste to achieve maximum mobilization is estimated at less than 20 days (Powell 1995).

10. It is assumed that the mixer pump $U_{0} D$ will be $2.7 \mathrm{~m}^{2} / \mathrm{s}\left(29.4 \mathrm{ft}^{2} / \mathrm{s}\right)$ at $1000 \mathrm{rpm}$ speed in the high shear sludge. The pump has been shown to achieve $U_{0} D=2.7 \mathrm{~m}^{2} / \mathrm{s}\left(29.4 \mathrm{ft}^{2} / \mathrm{s}\right)$ at $1000 \mathrm{rpm}$ in water. 


\subsection{TEST EQUIPNENT AND INSTRUMENTATION}

\subsection{MIXER PUMPS}

Two mixer pumps will be installed on opposite sides of the tank in risers 1C (south 107-cm [42-in.] riser) and $1 \mathrm{~A}$ (north 107-cm [42-in.] riser). A brief list of the characteristics of each pump is provided in Table 1.

Table 1. MIXER PUMP CHARACTERISTICS

\begin{tabular}{|l|l|}
\hline Pump type & Vertical line-shaft drive mixer pump \\
\hline Motor type & $\begin{array}{l}300 \mathrm{hp}, 1200 \mathrm{rpm}, 480 \mathrm{~V} / 3 \mathrm{PH} / 60 \mathrm{HZ} \text { weather- } \\
\text { protected enclosure }\end{array}$ \\
\hline Total pump weight & $\begin{array}{l}12,247 \mathrm{~kg}(27,000 \mathrm{lb}) \text { (water column } \\
\text { filled) }\end{array}$ \\
\hline Number of jet nozzles & $(2) 180^{\circ}$ opposed \\
\hline Diameter of each nozzle & $15 \mathrm{~cm}(6 \mathrm{in})$ \\
\hline Flow rate of each nozzle & $19,680 \mathrm{~L} / \mathrm{min}(5,200 \mathrm{gal} / \mathrm{min})$ 0 $1000 \mathrm{rpm}$ \\
\hline Uo each nozzle & $2.7 \mathrm{~m}^{2} / \mathrm{s}\left(29.4 \mathrm{ft}^{2} / \mathrm{s}\right)$ \\
\hline Jet flow direction & horizontal \\
\hline $\begin{array}{l}\text { Nozzle centerline } \\
\text { distribution above floor }\end{array}$ & 38 to $46 \mathrm{~cm}(15 \mathrm{to} 18 \mathrm{in})$. \\
\hline Pump rotation & $180^{\circ}$ oscillating at 0.05 to $0.2 \mathrm{rpm}$ \\
\hline
\end{tabular}

\subsection{MIXER PUMP MONITORING AND CONTROL SYSTEM}

The mixer pumps and instrumentation are monitored through an operator personal computer (OPC) and control console located in the AZ-156 building. Instrumentation on the console indicate the pump column water pressure and the pump column supply filter flow rate status. Table 2 contains the range/limit for these controls.

Table 2. MIXER PUMP CONTROL CONSOLE INDICATION

\begin{tabular}{|l|c|c|}
\hline & Range/Limit & Indication \\
\hline $\begin{array}{l}\text { Pump Column } \mathrm{H}_{2} \mathrm{O} \\
\text { Pressure }\end{array}$ & & \\
\hline - Normal & $40-60 \mathrm{psi}$ & Green \\
\hline - Low & $<40 \mathrm{psi}$ & Red \\
\hline $\begin{array}{l}\text { Pump Column } \\
\text { Supply Filter } \\
\text { Differential } \\
\text { Pressure (Flow) }\end{array}$ & & \\
\hline - Normal & $>0-<5 \mathrm{psi}$ & Green \\
\hline - High & $\geq 5$ psi & Red \\
\hline \hline TDD $=$ These will be established before the mixer pump test.
\end{tabular}


Additional instruments will be used to continuously monitor pump parameters through the OPC including motor bearing temperature, speed, frequency, current, voltage, and orientation. Mixer pump vibration will be measured locally using a hand held instrument during pump speed changes and startup. Tables 3 shows the alarm control logic for the mixer pump instrumentation.

Table 3. MIXER PUMP SYSTEM CONTROL LOGIC

\begin{tabular}{|c|c|c|c|}
\hline & Range/Limit & Variable & Action \\
\hline Motor bearing temperature: & $\begin{array}{l}-10^{\circ} \mathrm{C} \text { to } 130^{\circ} \mathrm{C} \\
\left(50^{\circ} \mathrm{F} \text { to } 266^{\circ} \mathrm{F}\right)\end{array}$ & & \\
\hline - High temperature & $120^{\circ} \mathrm{C}$ & $H i-W W$ & Alarm \\
\hline - Maximum temperature & $130^{\circ} \mathrm{C}$ & $\mathrm{HiHi}-\mathrm{WW}$ & $\begin{array}{l}\text { Pump off, } \\
\text { alarm }\end{array}$ \\
\hline Motor winding temperature: & $\begin{array}{l}\text { Rated }=\text { ambient }+ \\
70^{\circ} \mathrm{C}\left(126^{\circ} \mathrm{F}\right)\end{array}$ & & \\
\hline - Maximum temperature & $110^{\circ} \mathrm{C}\left(230^{\circ} \mathrm{F}\right)$ & $\mathrm{HiHi}-\mathrm{WW}$ & $\begin{array}{c}\text { Pump off, } \\
\text { al arin }\end{array}$ \\
\hline Pump current: & 50 to $364 \mathrm{~A}$ & & \\
\hline - High current & $320 \mathrm{~A}$ & $H i-W W$ & Al arm \\
\hline - Maximum current & $364 \mathrm{~A}$ & $\mathrm{HiHi-WW}$ & $\begin{array}{c}\text { Pump off, } \\
\text { a larm }\end{array}$ \\
\hline $\begin{array}{l}\text { Pump motor speed: } \\
\text { (calculated) }\end{array}$ & 700 to $1200 \mathrm{rpm}$ & & \\
\hline - Minimum speed & $700 \mathrm{rpm}$ & LoLo-WW & Indicator \\
\hline
\end{tabular}

$\mathrm{Hi}-\mathrm{WW}$ and $\mathrm{HiHi-WW}=$ Programmed in control console

\subsection{DATA ACQUISITION EQUIPMENT AND INSTRUMENTATION}

The following instrumentation and equipment must be operational in order to fully evaluate the mixer pump test objectives:

Installed by Project W-151:

- CCTV with VCR capabilities

- Gamma profilers

- Sludge thermocouples

- Profile thermocouples

- Strain gauges

- Ultrasonic Interface Level Analyzers

Existing:

- ENRAF liquid level detector

- Tank bottom thermocouples

- Airlift circulator thermocouples

- Continuous air monitor 
Existing(continued):

- Record sampler

- Gas sampling probe

Descriptions and functions of the instrumentation listed is described below. The locations of the instruments in tank 241-AZ-101 are shown in Figure 1.

\subsubsection{Closed-Circuit Television (CCTV)}

A CCTV camera will be installed through a riser in tank AZ-101 by the W-151 Project. The CCTV monitor will visually display any bending or moving of in-tank hardware during the mixer pump test and will be used to assist in the handling of any developing problems. The CCTV will be operated during the entire mixer pump test. The CCTV will also have VCR capabilities, which will be used during pump start up and speed changes.

\subsubsection{ENRAF Liquid Level}

The existing ENRAF liquid level detector is a microprocessor-controlled tank gauge which accurately measures the tank liquid level. The ENRAF data will be manually measured and recorded. The ENRAF liquid level gauge can be damaged when lowered into the tank waste during mixer pump operation, therefore, data will only be collected when mixer pumps are off. Measurements will be taken at intervals specified in tank farm operating procedures.

\subsubsection{Gamma Profiler}

The sludge mobilization monitoring equipment is designed to monitor total gamma activity at energies above Cesium-137. The system consists of a cadmium tellurium gamma detector deployed through the use of a portable utility cart. The utility cart contains a motorized cable spool and boom, position indicator, above-tank electronics, and power connections. Gamma activity can be monitored through the entire tank depth by raising or lowering the probe within a drywel1. Two gamma profilers are provided by the W-151 Project, that can be installed in numerous drywell locations in the tank. The gamma detectors will be used to determine gamma activity at a fixed location (drywell bottom), and to provide gamma profiles by recording data while moving the detectors to various elevations within the drywells. The gamma detectors will be used in the fixed position to provide additional data for determining the ECR, and in the profiling mode to help determine the degree of solids mobilization, the sludge settling rate, and the minimum pump speed required for maintaining waste mobilization. Baseline measurements will be taken at specific drywells prior to operating the pumps and at fifteen minute intervals while the pumps are operating. This instrument is manually operated and data will be recorded through the OPC.

\subsubsection{Thermocouples}

In-tank thermocouples will be used to measure the growth of the ECR, the degree of solids mobilization, and the change to the overall tank waste temperature, by monitoring temperature changes due to sludge movement and mobilization caused by the operation of the mixer pumps. Existing thermocouples include those at the tank bottom located just under the primary liner, and airlift circulator (ALC) thermocouples which protrude from the 
ALC's to within approximately $4^{\prime \prime}$ off the tank bottom. In addition, thermocouples installed by the W-151 Project will also be monitored, including sludge thermocouples located at the bottom of tank drywells, and profile thermocouple assemblies, which will monitor waste temperatures at approximately 4,12 and 158 inches off the tank floor. All thermocouple data will be manually read and recorded every 15 minutes, before, during, and after pump operation, at the 801-AY instrument building. All of tank 241-AZ-101 operational thermocouples used to monitor sludge mobilization are shown in Figure 2.

\subsubsection{Strain Gauges}

Strain gauges at three elevations, are mounted on two profile thermocouple probe assemblies. The strain gauges will be used to determine the impinging jet forces from the mixer pump. Strain gauge data will be measured continuously during mixer pump operation in the fixed and oscillating modes and recorded through the $O P C$.

\subsubsection{Ultrasonic Interface Level Analyzer}

Two Ultrasonic Interface Level Analyzers (URSILLA) will be provided by the W-151 Project. The URSILLA Model 2511 uses an ultrasonic ranging technique to measure the depth of the sludge interfaces within the tanks. A sensor is mounted approximately $5 \mathrm{~m}(15 \mathrm{ft})$ off the tank bottom. One of two crystals in the sensor assembly acts as a transmitter and generates short bursts of ultrasonic energy which travels in a narrow beam towards the tank bottom. The second crystal acts as a receiver to detect any resulting echoes. The analyzer measures the time delay and magnitude of these returning signals and stores this information in the form of a tank profile. The URSILLA will be operated continuously, and measurements will be taken and stored in the operator personal computer (OPC) at fifteen minute intervals.

\subsubsection{Ventilation System Monitoring Equipment}

Existing ventilation monitoring equipment will be used to determine if the operation of the mixer pumps will increase the amount of stack emissions and the amount of aerosols in the tank vapor space. Emissions will be monitored using the continuous air monitor (CAM) and a record sample will be taken after each pump run to determine any increase in emissions. Differential pressure readings across the HEPA filters and the deentrainers during the test will be compared to detect any additional aerosols in the tank vapor space. In addition, tank vapor samples will be taken to determine any vapor increases.

\subsection{SAMPLING}

Grab samples of Tank AZ-101 supernate will be obtained and analyzed to establishe a baseline data on the supernate solution and the amount of the suspended solids. The grab samples obtained are as follows:

- Before the start of the mixing pump test to establish baseline data on the supernate solution. 
WHC-SD-WM-PTP-027, Revision 2

- As soon as possible after testing of the first and second mixer pumps to determine the amount of suspended solids compared to baseline data.

Laboratory analysis will be performed on the grab samples to determine density, weight per cent total solids and dissolved solids, $\mathrm{pH}$, and particle size. The samples will also be characterized for chemical and radiochemical composition.

\subsection{TEST DATA ANALYSIS}

Double-shell Tank Retrieval Engineering will analyze the test data summarized below. The test data analysis will be used to compare actual results with predicted results to provide assurance that predicted performance can be made for other mixer pump retrieval systems. Retrieval Engineering will issue preliminary mixer pump test results as an internal memo shortiy after the conclusion of the test. A final approved mixer pump test report will follow and be released as a supporting document (see Section 11.0).

1. Estimate the percent of sludge mobilization. Compile temperature data from in-tank thermocouples, URSILLA data, gamma probe data and laboratory analysis to estimate the percentage of sludge mobilized.

2. Data from the URSILLA, the gamma probes, and the thermocouples will be used to determine the sludge particles settling rate after mixer pumps have been turned off (for individual and both pumps).

3. Estimate the force caused by the mixer pump jets on in-tank components. The stress from the mixer pump jets will be determined by the measurements taken from the strain gauges.

4. The CAM, vapor and record paper samples will be monitored during the test and then analyzed for any changes in the existing ventilation system exhaust stream.

5. Recommend design or operational improvements for future in-tank mixing or retrieval systems. When the mixer pump test has been completed, the compiled data shall determine which equipment and/or instrumentation was most effective, as well as aid in determining what is needed for follow-on retrieval systems.

6. After the waste is mobilized, both pumps will be operated to determine the minimum mixer pump speed required to maintain the mobilized solids in suspension. The specific instrumentation that will be used are the URSILLA, gamma probe, airlift circulators thermocouples, sludge thermocouples, and tank bottom thermocouples.

7. Sludge temperature monitoring will be used to estimate the ECR. Sludge temperatures will be recorded prior to mixer pump operations. After mixer pump startup, temperatures will be continually monitored. When a temperature change is noted at a thermocouple location, it will be assumed that the sludge has been mobilized out to that thermocouple location. If no temperature change is seen at the thermocouple location, it is assumed that the sludge was not mobilized. A comparison 
WHC-SD-WM-PTP-027, Revision 2

of all 45 sludge temperature locations will allow a plot of tank bottom sludge mobilization.

8. The operating profile (pump power versus time) of the mixer pump wi11 be compared with the simplified DST heat removal program to determine the accuracy and applicability of the program (Crea 1995).

\subsection{PROCEDURE}

\subsection{PRECAUTIONS AND LIMITATIONS}

As a prerequisite to the start of the test, the Project W-151 Operational Readiness Review will be completed, including authorization and safety basis documentation. Limits and requirements applicable to tank AZ-101 per current Operational Safety Requirements (OSR), Operating Specification Documents (OSD), Limiting Conditions of Operations ( $L C O)$, and Operating Procedures, will also apply during the test. In addition, the precautions and limitations listed below are also applicable during the conduct of this test.

\subsubsection{Pump Operation}

The Notice of Construction (NOC) revision for tank AZ-101 operation, states that the mixer pumps will not exceed a nominal 800 hours of operation in FY 96 , and 1300 hours of mixer pump operation during FY 96 and FY 97

combined. If the mixer pumps have to run more than the nominal 800 hours, the Environmental Compliance and Support Group will be contacted and they will decide whether the mixer pump test will proceed. Accumulative running of hours will be logged in the procedure.

\subsubsection{Motor Bearing Temperature}

An alarm will be sounded when the motor bearing temperature exceeds $120^{\circ} \mathrm{C}$. When the motor bearing temperatures exceed $130^{\circ} \mathrm{C}$, the pumps will be manually turned off.

\subsubsection{Pump Motor Temperature}

The pump motor temperature is calculated by the VFD by measuring current through the pump motor windings. The manufacturer has recommended a limit for operation of $230^{\circ} \mathrm{F}$ (CVI 1995). Output from the VFD is interlocked with pump power and will trip the pump if the calculated temperature exceeds this value.

\subsubsection{Pump Current}

The rated full load current is $364 \mathrm{~A}$. Exceeding this current the motor will become overheated. Output from the VFD is interlocked with pump power and will trip if the sustained current exceeds this value. Trip time is approximately 60 seconds at $150 \%$ of rated current. 


\subsubsection{Minimum and Maximum Pump Operation}

The mixer pump design operational speed varies between 700 and $1200 \mathrm{rpm}$, or not to exceed $364 \mathrm{~A}$. The design of the lower mechanical seal limits lowspeed operation of the mixer pumps to $\geq 700 \mathrm{rpm}$. The pump motor speed is calculated by the VFD based on output frequency and motor slip characteristics. Minimum and maximum speeds are set in the VFD. Depending on fluid characteristics, the pump may reach full rated current at less than 1200 RPM. Output from the VFD is interlocked with the pump power and will trip the pump if the sustained pump current exceeds a value of $364 \mathrm{~A}$.

\subsubsection{Strain Limits for In-Tank Equipment}

The strain gauges, air lift circulator thermocouples, new sludge thermocouples, and new profile thermocouples are reported in the structural analysis to be structurally adequate for the pump nozzle jet-induced loads at full pump speed.

\subsection{GENERAL SEQUENCE FOR MOBILIZATION OF SOLIDS}

The general sequence of testing and data analysis is outlined below. A detailed test procedure will be prepared by DST Retrieval Engineering outlining specific instructions for conducting the mixer pump test. Throughout the duration of the test, while the pumps are operated at various speeds both in a fixed and operating mode, data from CCTV, thermocouples, gamma probes, and URSILLAs will be monitored and recorded. Data from other instrumentation will be monitored and recorded at specific times during the test as stipulated below.

1. Take a grab sample before mixer pump test.

2. Before pump operation, measure and record the following: liquid level, thermocouples, gamma profiler, strain gauges, CCTV, and URSILLA.

3. Orient pump no. 2 in the fixed position identified as index area \#1 on Figure 3. Operate pump no. 2 at $700 \mathrm{rpm}, 1000 \mathrm{rpm}$, and at maximum speed at full power of full load amps. The pump should be run for a minimum of 8 hours at each speed until instrumentation indicate that there is no further sludge mobilization. Index area no. 1 covers the following line of operational air lift circulator thermocouples which will be used to determine the ECR:

- TE-101-53, 7 feet - TE-101-43, 23 feet

- TE-101-42, 11 feet - TE-101-58, 42 feet

4. Orient mixer pump no. 2 in the fixed position identified as indexed area no. 2 on Figure 3 , and repeat testing as per step 3 . This position is located approximately $90^{\circ}$ from indexing area $\# 1$. Index area no. 2 covers the following line of operational air lift circulator thermocouples which will be used to determine the ECR:

$$
\begin{aligned}
& -\quad T E-101-41,11 \text { feet } \\
& \therefore \quad T E-101-40,29 \text { feet } \\
& -\quad T E-101-49,42 \text { feet }
\end{aligned}
$$


5. Operate mixer pump No. 2 in the oscillating mode at $700 \mathrm{rpm}, 1000 \mathrm{rpm}$, and at maximum speed at full power of full load amps for a minimum of 8 hours at each speed and record data. Continue operating pumps at each speed until the instrumentation indicates that there is no further sludge mobilization.

6. Operate mixer pump No, 1 and 2 in the oscillating mode at $700 \mathrm{rpm}, 1000$ rpm, and at maximum speed at full power of full load amps for a minimum of 8 hours at each speed and record data. During operation of the pumps monitor strain gauge readings through a minimum of five complete oscillation of the pumps at each speed. Continue operating pumps at each speed until the instrumentation indicates that there is no further sludge mobilization.

7. After the pumps have been shut off, obtain a grab sample as soon as possible.

\subsection{GENERAL SEQUENCE FOR MAINTAINING MOBILIZED SOLIDS IN SUSPENSION}

Ramp both pumps up to full speed or until instruments indicate sludge is mobilized. Lower the pumps speed incrementally until instruments indicate sludge settling. At that point, raise speed until remobilized and record.

\subsection{SAFETY}

The Unreviewed Safety Question (USQ) Evaluation is currently being resolved to close all yes/maybe responses (Kidder 1994). The resolution of the USQ Evaluation may require changes in the Tank Waste Remediation System (TWRS) Safety Authorization Basis to include the case of the operation of two mixer pumps within the safety envelope. Concurrently, the distribution of fissile material by mixer pumps is not addressed in the Criticality Safety Evaluation Report (CSER) for AZ Tank Farms. The disposition of this issue will be determined by the TWRS Criticality Safety Representative. All issues will be resolved prior to mixer pump operations and these actions will be documented in readiness review activities and documents.

Any safety issues resolution necessary for mixer pump operations will be addressed by Project $W-151$ and included in closure documents for both the USQ Evaluation and the CSER.

\subsection{QUALITY ASSURANCE}

\subsection{INSTRUMENT CALIBRATION}

Instruments will be calibrated in a manner appropriate to their use in the test. For test instruments covered by the American Society for Testing Materials (ASTM) testing and calibration standards, the test/calibration procedures will be compared to the ASTM standards and procedures will be corrected, if necessary. 
For instruments which are not addressed by ASTM standards, calibration procedures will be prepared consistent with the general principles that guide the formulation of acceptable calibration and operating procedures, taking into account limitations that may be imposed by operation in a nuclear waste tank.

Instruments will be calibrated before installation in the waste tank, using standards traceable to the National Bureau of Standards, where possible.

\subsection{HITNESSING TESTS}

Quality Assurance personnel will witness the testing, as necessary.

\subsection{SCHEDULE}

Figure 4 is a schedule for the AZ-101 mixer pump test. This schedule was incorporated into the A-Complex schedule. The A-Complex schedule is updated weekly by Retrieval Program and delivered to upper management in TWRS.

\subsection{FUNCTIONAL RESPONSIBILITIES}

To support this process test, the following responsibilities have been assigned to the organizations 1 isted. Specific assignments of responsibilities, facility access controls, communication links, etc., will be provided in a Memorandum of Understanding issued prior to conducting the Test.

Disposal Engineering

- Test Plan preparation
- Test Procedure preparation
- $\quad$ Engineering technical support
Test report preparation

Operations and Maintenance

- Test direction and control

- Test performance

- Data collection

\section{Projects}

- Project $W-151$ interface

Qual ity Assurance

- Quality surveillance and oversight

Characterization

- Sample collection and analysis 


\subsection{REFERENCES}

Crea, B. A., 1995, Simplified DST Heat Removal Program, letter 74220-95-BAC030, Westinghouse Hanford Company, Richland, Washington.

CVI, 1995, Lawrence Operating and Maintenance Manual, Customer Vendor Information, 22515, Westinghouse Hanford Company, Richland, Washington.

Hodgson, K. M., 1995, Tank Characterization Report for Double-shell Tank 241$A Z-101$, WHC-SD-WM-ER-410, Westinghouse Hanford Company, Richland, Washington.

Kidder, R. J., 1994, Transmittal of the Tank 241-AZ-101 Waste Retrieval System USQ Evaluation for Project W-151, internal memo 8D111-RJK-94009, Westinghouse Hanford Company, Richland, Washington.

Maclean, G. T., 1995, Tank AZ-101 Decant and Refill Test Plan, WHC-SD-WM-PTP-028, Westinghouse Hanford Company, Richland, Washingtion.

OSD, 1994, Operating Specifications for the 241-A-702 Vessel Ventilation System, 0SD-T-151-00016, L. M. Bergman, Westinghouse Hanford Compariy, Richland, Washington.

OSD, 1996a, Operating Specifications for 241-AN, AP, AW, AY, AZ and SY Tank Farm, OSD-T-151-00007, Rev/Mod H-17, Westinghouse Hanford Company, Richland, Washington.

OSD, 1996b, Operating Specification for Aging-Waste Operations in 241-AY, and 241-AZ, OSD-T-151-00017, L. M. Bergman, Westinghouse Hanford Company, Richland, Washington.

OSR, 1996, Aging Waste Facility Interim Operational Safety Requirements, WHCSD-WM-0SR-004, Rev. 1B, Westinghouse Hanford Company, Richland, Washington.

Powe11, M. R., 1995a, FY 1993 1/25 Scale Sludge Mobility Testing, PNL-10464, Pacific Northwest National Laboratories, Richland, Washington.

Powell, M. R., 1995b, Fiscal Year 1994 1/25-scale with sludge Mobilization Testing, PNL-10582, Pacific Northwest laboratory, Richland, Washington.

Stegen, L. C., 1988, Technical Program Plan for Retrieval of Solids from Aging and Non-aging Waste Tanks, SD-WM-TPP-041, Rockwe11 Hanford Operations, Richland, Washington.

Waters, E. D., 1992, Functional Design Criteria, Project W-151, Tank 101-AZ Waste Retrieval System, WHC-SD-W151-FDC-001, Rev. 2, Richland Washington 
Figure 1 Location of instrumentation to monitor AZ-101 process test.

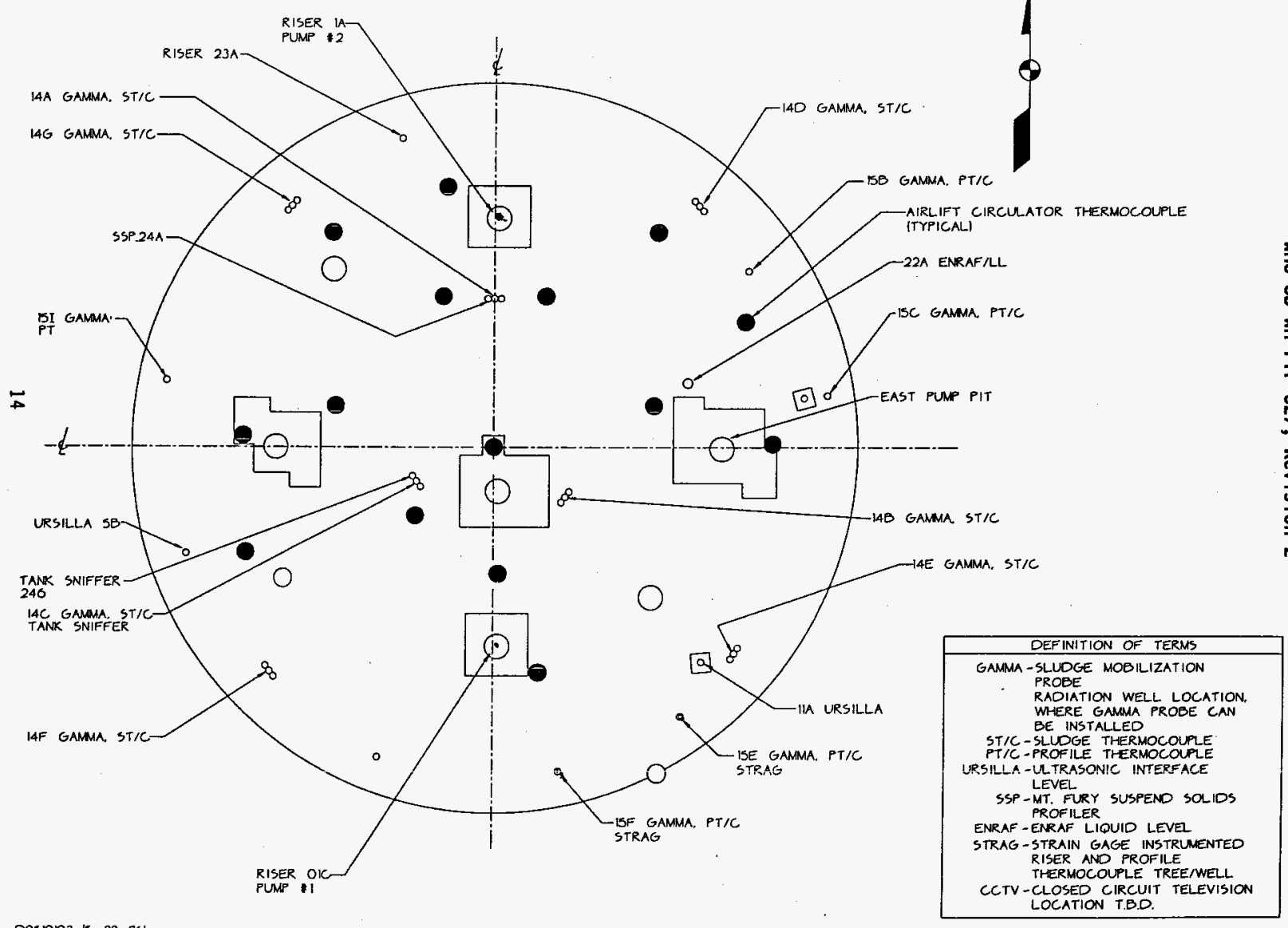


WHC-SD-WM-PTP-027, Revision 2

Figure 2. Operational Thermocouples Which Will Monitor Sludge Mobilization.

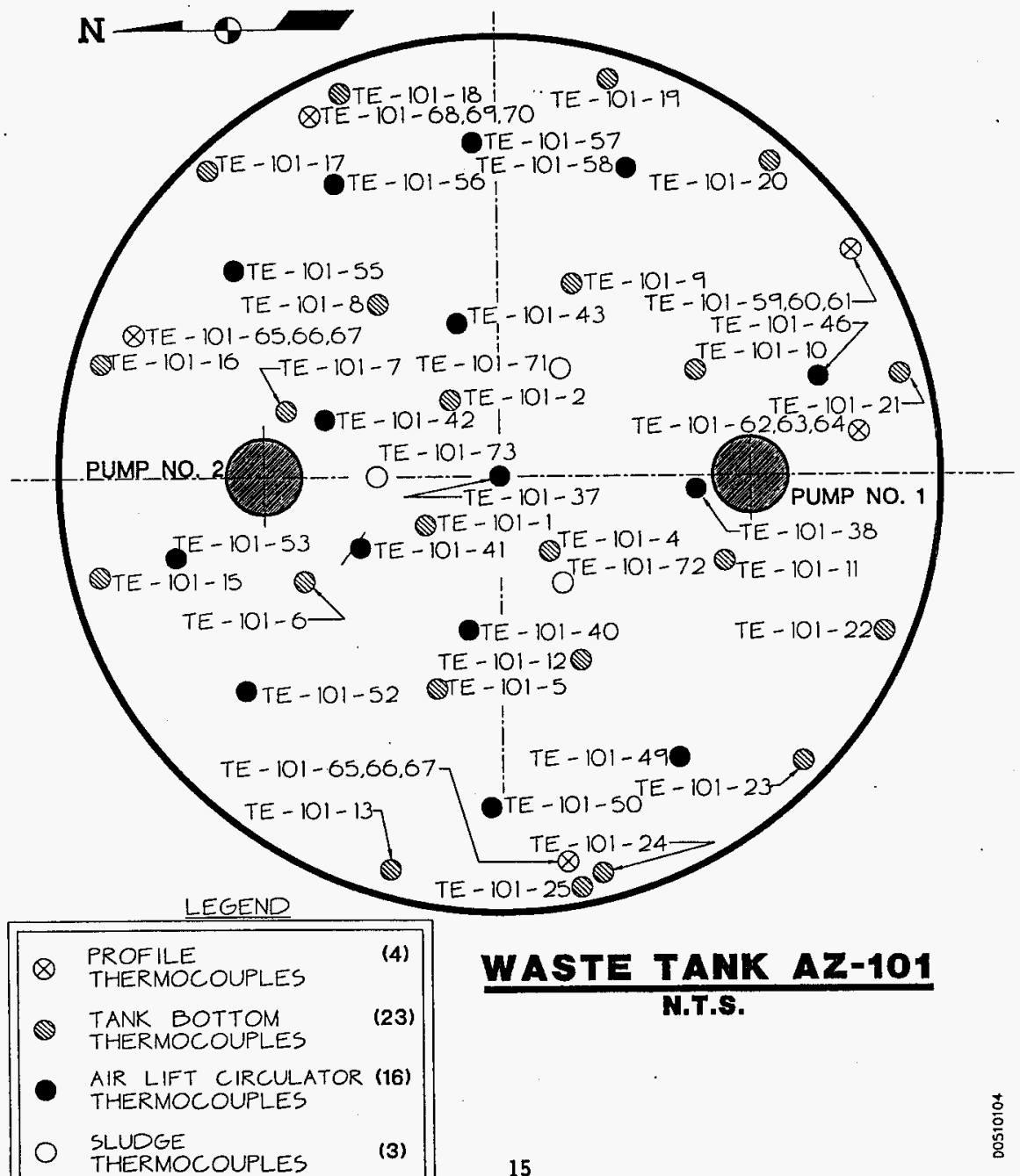


Figure 3. Operational Thermocouples Which Will Monitor Sludge Mobilization with Indexing Areas

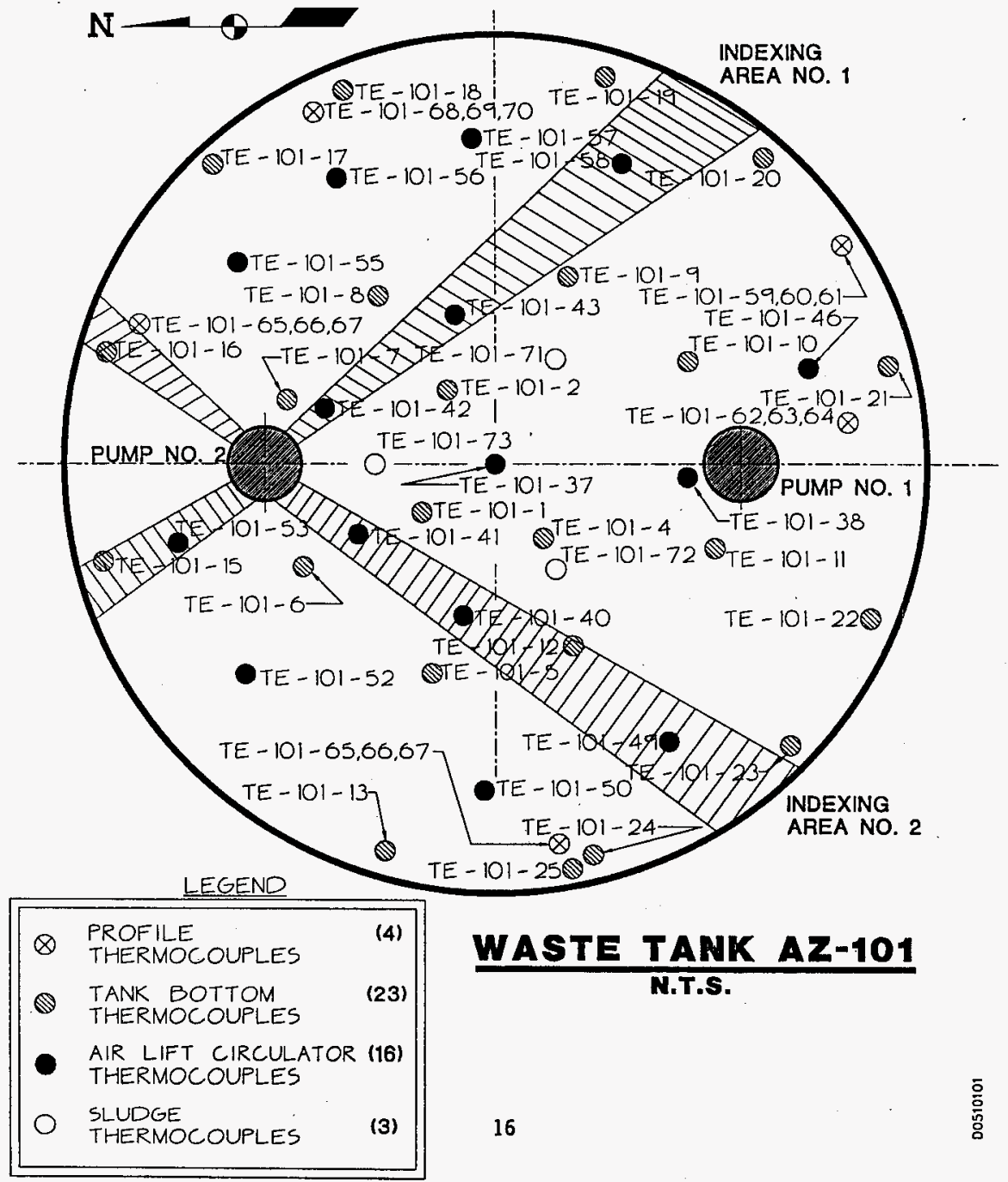




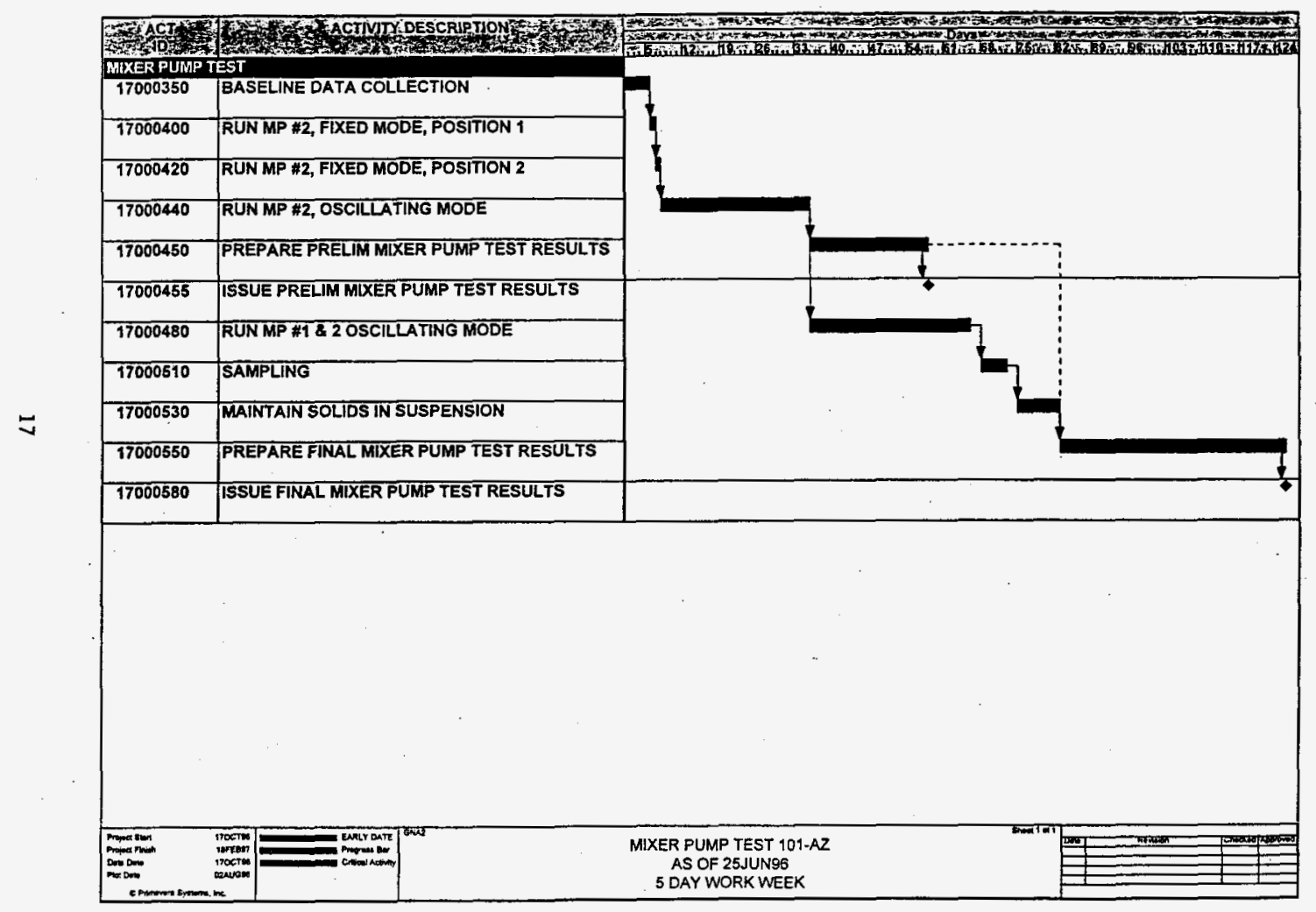

